\title{
STUDY ON CONSUMER PREFERENCES TOWARDS ORGANIC FOOD IN THE MARKET OF SPLIT
}

\author{
Marin Čagalj ${ }^{1}$, Ivo Grgić2 Josip Gugić ${ }^{3}$ \\ *Corresponding authorE-mail: marin.cagalj@krs.hr
}

\begin{abstract}
A R T I C LE IN F O
A B S T R A C T

Review Article

Received:15 October 2019

Accepted: 05 January 2020

doi:10.5937/ekoPolj2001285C

UDC 339.372.5:631.147(497.13 Split)

Keywords:

organic food, consumer

preferences, Split market, Croatia

JEL: D12, D20

Since the nineties of the last century, ecological products have become increasingly important in the market, and given that scientists have pro and contra arguments of ecological breeding, the main purpose of this paper was to determine the consumer's preferences towards ecological food; the importance of certain characteristics and deterrents on the purchase of organic food; in the market of Split. For this survey we randomly recruited 113 participants in Split, Croatia. Surveyed consumers when purchasing organic food of the greatest importance consider protection of the environment, and at the least important they retain the taste. The most significant constraint on purchasing organic food of surveyed consumers is the high cost of the product, and the least important is the lack of marketing. Given the size of the sample, surveyed consumers are a typical target group of consumers of organic food.
\end{abstract}

(C) 2020 EA. All rights reserved.

\section{Introduction}

Since the 1990's, organic produces have occupied a more and more important place in the market. Organic farming is growing out of the niche. From now on it receives political supports and it includes industrially processes. The current expansion of organic farming and its recognition as one of the main forms of sustainable agriculture (its image is often idealized among people) raises many controversial debates among scientists about pro and contra arguments of organic agriculture. The most obvious advantage of the organic farming, among many benefits, over the other agricultural production methods is usage of environmentally sustainable systems in crop and livestock production. Advantage is usage of farmers' traditional knowledge in their

1 Marin Čagalj, Ph.D, Institute for Adriatic Crops and Karst Reclamation, Put Duilova 11, 21 000 Split, Croatia, +38521434492, marin.cagalj@krs.hr, ORCID ID https://orcid.org/00000003-4193-7759

2 Ivo Grgić, Ph.D., Faculty of Agriculture University of Zagreb, Svetošimunska 25, 10000 Zagreb, Croatia, igrgic@agr.hr, ORCID ID (https://orcid.org/0000-0003-3900-4925)

3 Josip Gugić,Ph.D., University Department of Marine Studies, Ruđera Boškovića 37, P.O. Box 190, 21000 Split, Croatia,jgugic@unist.hr 
natural environment (Closter et al., 2004). Avoid of chemical inputs in production is another advantage of organic farming (Laird, 2001). Several studies found that organic farming reduces health risks (Foley, 2006; Azadi and Ho, 2010). One of the reasons of purchasing organically produced food is perception that organic food possesses a better quality (Randerson, 2004: Azadi and Ho, 2010) than the food products produced with other farming methods. Study (Foley, 2006) found that organically produced food do not contain residues of the pesticides. Another several studies found that organically produced food possesses intense and realistic taste and flavors (Foley, 2006). Other advantages of organic farming such as reduction of pollution (Lampkin and Midmore, 1999), conservation of insects (Azadi and Ho, 2010), creation of new jobs (Holden, 2004), enhancement of soil fertility (Azadi and Ho, 2010; Lampkin and Midmore, 1999), improvement of animal welfare (Holden, 2004), conservation and promotion of biodiversity (Lampkin and Midmore, 1999; Balfour, 2003), lower cost production method (Foley, 2006) were found in literature review of organic farming.

Conversely of pro arguments, in literature review were found contra arguments of organic farming. No serious study has succeeded in demonstrating scientifically that organic food is healthier (Houdebine, 2010; Durand-Parenti, 2011; Johnston, 2008). Reviews show that the chemical and biochemical composition of organic produces differs only very little from the same conventional produces (Houdebine, 2010), concerning the nutritional differences and taste. Houdebine (2010) found that most of the time an organic produce does not taste better than its conventional namesake as a lot of blind tests show. From environmental safety and sustainability point of view there are also arguments against organic farming. Concerning pesticides and pollution, a major issue is the use of energy in organic farming. Mechanical weeding, which is a significant alternative to pesticides used by organic farmers, consumes a lot of petrol (Durand-Parenti, 2011). Moreover, Johnston (2008) reports the example of the production of a liter of organic milk, which requires $80 \%$ more land than conventional milk to produce. Thus, the production of a type of organic tomatoes in the UnitedKingdom uses 25\% more water than conventional production. Important issue that appears in organic farming is area needed to produce natural pesticides and fertilizers. In his paper, Houdebine (2010) observes that there is no answer to the question whether it is possible to produce huge quantities of natural pesticides and organic fertilizers without using important areas at the expense of food crops. In contrast the use of intermediate crops and the biological pest control with beneficial organisms are really good innovations.

Concerning the mentioned pro and contra arguments of organic farming, the main purpose of this work was to find out preferences of Croatian consumers towards organic food. Another objective of particular interest was to find out knowledge in organic farming; importance in buying organic food, and deterrents of buying organically produced food among buyers at market in Split. 


\section{Materials and methods}

For this survey we randomly recruited 113 participants in Split, Croatia. Data collection took place from September to November 2017. Participants in this research were chosen randomly following "each second consumer approach". Among those willing to participate in the research, dropout rate was $17.1 \%$. One of the restrictions for this survey and recruitment of participants was that they are over 18 years old. Reason why we decided for this restriction was that only adult participant has income, knowledge and makes purchasing decision independently. Places of recruitment of participants for survey were grocery stores, open-air market of fresh fruits and vegetables and supermarkets. Our sample is large enough and contains all adult participants with different socio-economic backgrounds (income, education, knowledge about organic food). Participants in this survey were asked to fill in the questionnaire. Questionnaire was given to the participants to collect some socioeconomic background information about our sample. Questionnaire contains open-ended questions (completely unstructured questions and word-association questions) and closed -ended questions (dichotomous or two-point questions, multiple choice questions and scaled questions). We used Likert five-point scale with responses ranged from a group of categoriesleast (1) to most (5) - asking participants to indicate how much they agree or disagree, approve or disapprove with statements. All statistical analysis of collected data was done by the statistic program " $\mathrm{R}$ " ( $\mathrm{R}$ Core Team, 2012), version 2.14.1.

\section{Results and Discussion}

The sample demographics were captured in the questionnaire. Sample characteristics are summarized in the Table 1. The places of survey were selected to meet the target group of buyers of organic products. In research (Martic-Kuran and Mihic, 2014) on consumer behavior in purchasing organic food in Croatia authors concluded that the subjective standards (consumers' surrounding) have great intention on purchase of organic food products. The average age of respondents in this survey was 34 . The high share of students among interviewed consumers explains the lower average age. The percentage of women in this survey was $57,9 \%$ being woman. Highest share of the participants $(54,7 \%)$ in this survey had a University degree. Participants with finished high school was $40,9 \%$, and 3,0\% finished with elementary school. More than half of the participants $(50,3 \%)$ had household's income above $15,000 €$ per year, $37.2 \%$ had an income between $10,000 €$ and $15,000 €$ and only $9.8 \%$ below $10,000 €$. In our sample, $42.0 \%$ of participants were formally employed, $29.1 \%$ were students, $11.3 \%$ were retired, $11.6 \%$ self-employed and $6,0 \%$ participants were farmers. As a part of questionnaire we asked participants if they had children in their household. Results revealed that $46.5 \%$ participants have children in their household. 
Table 1. Sample characteristics $(\mathrm{N}=113)$

\begin{tabular}{|c|c|c|}
\hline \multirow[t]{2}{*}{ Variable } & \multicolumn{2}{|c|}{ Categories } \\
\hline & Mean & St. Dev. \\
\hline Age (years) & 34.83 & 11.01 \\
\hline Gender & \multicolumn{2}{|c|}{$\%$} \\
\hline Male & \multicolumn{2}{|c|}{42.1} \\
\hline Female & \multicolumn{2}{|c|}{57.9} \\
\hline Education & \multicolumn{2}{|c|}{$\%$} \\
\hline Elementary school & \multicolumn{2}{|c|}{3.0} \\
\hline High school & \multicolumn{2}{|c|}{40.9} \\
\hline University & \multicolumn{2}{|c|}{54.7} \\
\hline None & \multicolumn{2}{|c|}{1.4} \\
\hline Household income (€ /year) & \multicolumn{2}{|c|}{$\%$} \\
\hline Low income $=$ less than $10,000 €$ & \multicolumn{2}{|c|}{9.8} \\
\hline Mid income $=$ between $10,000 €$ and $15,000 €$ & \multicolumn{2}{|c|}{37.2} \\
\hline High income $=$ more than $15,000 €$ & \multicolumn{2}{|c|}{50.3} \\
\hline \multirow[t]{2}{*}{ No answer } & \multicolumn{2}{|c|}{2.7} \\
\hline & Mean & St. Dev. \\
\hline $\begin{array}{l}\text { Planned to buy organic } \\
\text { food on the day of interview }\end{array}$ & 0.71 & 0.27 \\
\hline
\end{tabular}

Participants in our sample are younger, with a higher income and were better educated than the average Croatian consumer. Concerning the sample size we concluded that this is the typical target group for organic food, while not representative for the whole Croatian population.

The large majority of participants in this survey knew about organic food products (94.1\%) and had bought organic food at least once (87.6\%). In this research 52.3\% participants heard/read about organic food from media (TV, radio, Internet, newspaper), $21.9 \%$ read in books about organic food, $24.2 \%$ heard/read at the school/university and $1.6 \%$ participants from other sources heard/read about organic food. Results of this survey revealed that the large majority of respondents $(94.1 \%)$ knew about organic food. This finding is much greater finding for knowledge about organic food among Croatian consumers than reported (34\%) in another study (Stefanic et al., 2001) from Croatia.

To reveal the frequency of buying organic food, interviewed participants were asked about the frequency of buying organic food. In questionnaire answers on this question were divided into groups; "Heavy buyers"- buying every day, "Medium buyers"buying every week, "Light buyers"- buying once a month and group "Never"- never buying organic food products. Results revealed that $40.3 \%$ of participants are buying organic food every week, $36.1 \%$ once a month and $22.5 \%$ every day, and $1.1 \%$ have never bought organic food. 
Participants in this survey were also asked how many organically produced food (quantity) they have in their household. Large majority of $63.0 \%$ participants have at least 1 organically produced food products in household, $23.5 \%$ more than 2 organically produced food products, $2.1 \%$ participants have more than 3 organically produced food products and $11.4 \%$ didn't have any organically produced food product in their household on the day of the interview.

To reveal what is important why the participants buy organic food, we asked participants to sort and begin from what the most important to them (5) and finish with less important (1) following statements (Likert scale): protection of environment; healthy; better taste; free of chemicals from pesticides and herbicides; prevention of diseases; and higher quality.

Results revealed (Table 2.) that 47,7\% participants consider protection of environment as most important, on the second place $15.8 \%$ is free of chemicals, on the third place $11,1 \%$ healthy, on the fourth place $11,0 \%$ higher product quality, on the fifth place $7,6 \%$ prevention of diseases and in the end 6,8\% participants with taste. Results revealed in this study are contrary from other studies (Kovacic et al., 2002; Stefanic et al., 2001; Martic-Kuran and Mihic, 2014; Cerjak et al., 2010) in Croatia towards most important motive of purchasing organic food products, where it was found that Croatian consumers see health as most important motive.

Table 2. Importance in buying organic food $(\mathrm{N}=113)$

\begin{tabular}{|l|c|c|}
\hline & M & SD \\
\hline Protection of environment & 4.34 & 0.908 \\
\hline Healthy & 3.79 & 0.977 \\
\hline Better taste & 2.88 & 1.061 \\
\hline Free of chemicals & 3.89 & 1.071 \\
\hline Prevention of diseases & 3.54 & 0.985 \\
\hline Higher quality & 3.68 & 1.145 \\
\hline
\end{tabular}

As deterrents of buying organic food participants have the six statements (high price premiums; lack of organic food availability; low trust in certification boards and organic labels; insufficient marketing; satisfaction with current food choice and sensory defects) to choose three most important (Table 3.) using Likert scale (1- less important to 5 - most important).

The results revealed (Table 3.) that $32,4 \%$ participants as the most important deterrent in buying organic food consider high price premium, 30,7\% participants consider current food choice, $24,1 \%$ participants consider lack of organic food availability, $10,8 \%$ participants consider low trust in certification boards and organic labels, $2,0 \%$ participants consider insufficient marketing. Interesting is that no one of participants in this research consider sensory defect as deterrent of purchasing organic food. 
Table 3. Deterrents of buying organic food $(\mathrm{N}=113)$

\begin{tabular}{|l|c|c|}
\hline & M & SD \\
\hline High price premiums & 4.37 & 0.790 \\
\hline lack of organic food availability & 3.91 & 0.958 \\
\hline Low trust in certification & 3.18 & 1.231 \\
\hline Insufficient marketing & 2.95 & 1.061 \\
\hline Satisfaction with current food choice & 4.14 & 0.927 \\
\hline Sensory defects & 0 & 0 \\
\hline
\end{tabular}

\section{Conclusions}

In the last decade, especially after Croatia become a EU Member State (2013) significant increase in the area and the number of farms involved in organic farming are recorded. In Croatia certified organic food production is substantially lower than in higher income EU countries, even though Croatia implemented all EU regulations concerning Organic Food production and labeling. Though, many products in Croatia which are produced as organic are not certified and labeled. For producers, processors and marketing overall, this causes difficulties because many of the benefits of organically produced food thus cannot be communicated and are hidden to the consumer when buying or consuming organic food. Beside the market development and increase in demand for organic food products, reason for high interest of farmers to involve in this sector lie in the fact of support and subsidies for organic food production. Another reason is also higher price premiums for this kind of food products. Croatia still has environmental resources, such as uncultivated arable land, especially in rural areas to increase the volume of organic food production volume. Another potential is Mediterranean climate at the whole Croatian coastal area. The domestic organic food market is unfortunately still not properly organized and controlled (scandal with largest organic producer and retailer in 2015), and this is the reason for additional efforts that need to be made in the development of market infrastructure, marketing activities and monitoring of organic food products to increase the consumers' confidence in organic labels. Tourism as one of the key element of Croatian economy is another potential for organic food sector. Substantially younger consumers at the market worldwide, as well at Croatian market recognize the benefits of organic farming and one of the key elements of Croatian institutions are to educate and inform population, especially children of all benefits of organic farming on environment, biodiversity, animal welfare and health. Beside the education of consumers, it is important to educate the farmers in organic farming to not only produce the organic food because the subsidies those are actually higher than in conventional farming.

\section{Conflict of interests}

The authors declare no conflict of interest. 


\section{References}

1. Azadi, H., and Ho, P. (2010). Genetically modified and organic crops in developing countries: A review of options for food security. Biotechnology Advances 28; 160 168. DOI:10.1016/j.biotechadv.2009.11.003

2. Balfour, E. (2003). Land health. http://www.sheepdrove.com/article.asp?art $\mathrm{id}=111$ Buck, D., Getz, C., and Guthman, J. (1991). From farm to table: the organic vegetablecommodity chain of Northern California. Sociologica Ruralis, 37 (1), 3-20.

3. Cerjak, M., Mesic, Z., Kopic, M., Kovacic, D., and Markovina, J. (2010). What Motivates Consumers to buy Organic Food: Comparison of Croatia, Bosnia and Herzegovina, and Slovenia. Journal of Food Products Marketing 16 (3); 278-292. https://doi.org/10.1080/10454446.2010.484745

4. Closter, A.M., Embree E., Petersen, M., and Pedersen, S.H. (2004). Organic farming and genetically modified crops in relation to food security. Henning Høgh Jensen Publication.

5. Croatian Bureau of Statistic (2015). Average monthly net and gross earnings of persons in paid employment. First Release, 9.1.1.

6. Foley, C.L. (2006). Making the organic connection. http://www. organicconnection. net/

7. Durand-Parenti, C. (2011): Rien ne prouve que le bio soit meilleur pour la santé. Published by Le Point.fr, at: http://www.lepoint.fr/societe/rien-ne-prouve-que-lebio-soit-meilleur-pour-la-sante-05-04-2011-1315682_23.php

8. Holden, P. (2004). Organic advantages. http://www.theguardian.com/news/2004/ may/10/food.foodanddrink

9. Houdebine L., M. (2010). Dix questions sur l'agriculture biologique. Afis science et pseudosciences 290 .

10. Johnston, R. (2008). The great organic myths: Why organic foods are an indulgence the world can't afford. Published by The Independent. http://www.independent. co.uk/environment/greenliving/the-great-organic-myths-why-organic-foods-arean-indulgence-the-world-cant-afford-818585.html (accessed on 20.01.2013).

11. Kovacic, D; Radman, M; Haas, R. (2002). Segmentation of city market customers in Croatia - Towards a marketing strategy for fruit and vegetable markets. Die Bodenkultur. Austrian Journal of Agricultural Research, 53 (4); 207-216.

12. Laird, E. (2001). Low federal support for organic farming. Alive:230.

13. Lampkin, N., and Midmore, P. (1999). Organic farming and the European Union. Memorandum of evidence to the House of Lords select committee on the European communities sub-committee D (Agriculture, Fisheries and Food).

14. Martic Kuran, L. and Mihic, M. (2014). Applying the theory of planned behavior in the purchase of organic food. Market; 26 (2) 
15. R Core Team (2012). R: A language and environment for statistical computing. R Foundation for Statistical Computing, Vienna, Austria. ISBN 3-900051-07-0, URL http://www.R-project.org/.

16. Randerson, J. (2004). Organic farming boosts biodiversity. Biological Conservation $122: 113$.

17. Stefanic, I., Stefanic, E. and R. Haas (2001). What the customers really want: organic food market in Croatia? Die Bodenkultur. Austrian Journal of Agricultural Research, 52 (4); 243-248. 